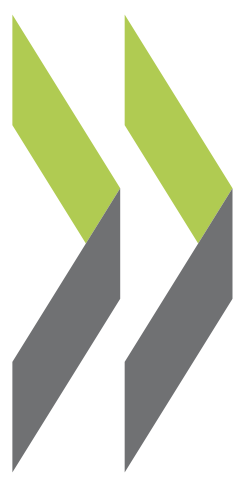

PEB Exchange, Programme on Educational Building 2005/11

\title{
Structures for Learning \\ in New Zealand
}

\section{Bruce Sheerin}

https://dx.doi.org/10.1787/546113043454 


\section{STRUCTURES \\ FOR LEARNING \\ IN NEW ZEALAND}

The New Zealand Ministry of Education is undertaking a project to provide information that can assist schools to design quality environments that will improve student learning outcomes.

The project started in 2004 with the ministry surveying boards of trustees, principals, teachers and students on what features of property design they believed were important to support students' learning. As part of this project the ministry is identifying current design standards that need to be followed and publishing examples of best practice in design solutions. The objective of this is to encourage schools to network and learn from each other's experience.

The work looks at the requirements for the internal environment of spaces such as acoustics, ventilation, heating and lighting. It also considers changing curriculum and teaching practice and what this might mean for teaching space design, the impact of different types of school organisation on school layout as well as other factors such as sustainability in design, the requirements for special needs students, information and communications technology, and security.

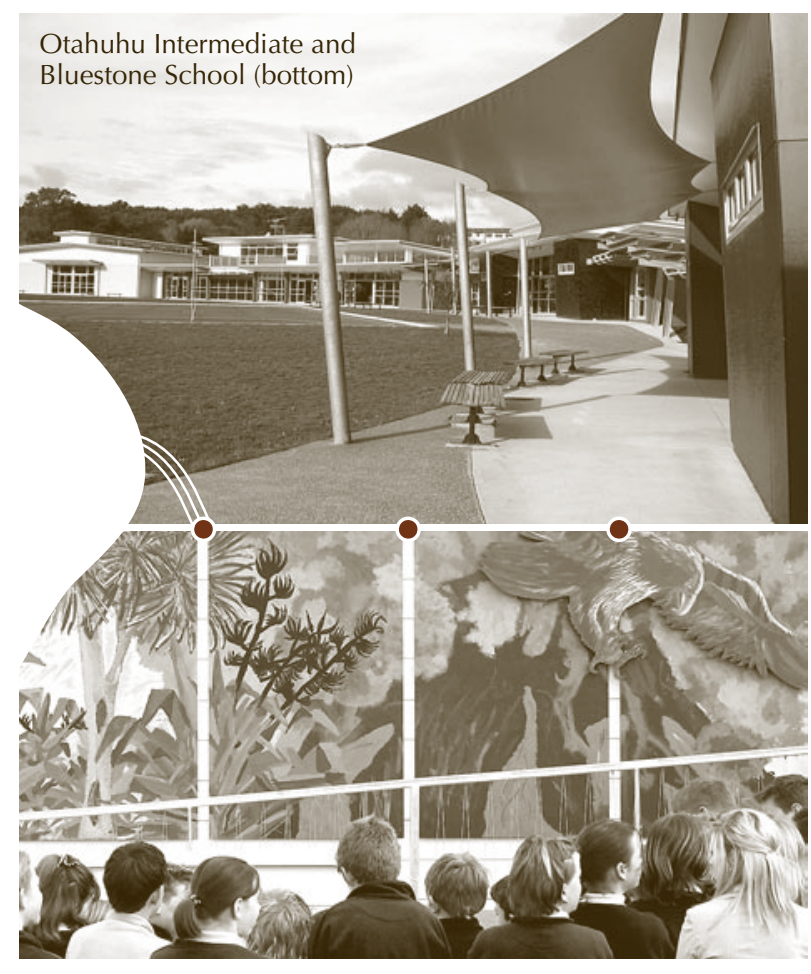

In New Zealand, decision-making on school property is devolved to school boards of trustees. With their five-year budgets, school boards have complete freedom to decide how to how to modernise and maintain their buildings. ${ }^{1}$ This makes them particularly eager to know what other schools are doing.

The survey carried out by ACNielsen revealed that most boards of trustees, principals, teachers and students share similar views on what is important in school design to promote learning.

\section{Survey results: Otahuhu Intermediate}

Otahuhu Intermediate (years seven and eight) was one of 15 schools to participate in the survey. The school principal, Athol Cartwright, said his students were enthusiastic to be asked for their opinions and were quick to identify aspects of property design that support their learning. The board of trustees and teachers also appreciated the opportunity to contribute to the property project.

Some 30 students participated in the survey after being briefed by their teachers on its objectives. "We told them to disregard cost in this exercise and asked what their ideal learning environment would be," explained the principal. The students identified open and well ventilated classrooms with natural light and good indoor/outdoor flow as important. A priority, particularly among the school's Polynesian students, was having enough personal space in the classroom to minimise peer distractions and enable free movement when engaging in a variety of learning activities around the classroom.

The students also identified the importance of having space for computers and of this space being arranged in such a way that those working on computers would not distract others working on non-computer related activities.

Some of the school's building planning has changed as a result of the survey.

\section{Design example: Bluestone School}

Bluestone School is one of a number of schools identified by the Ministry of Education as using property design innovatively to improve learning. Accommodating an extra 200 students as the result of a merger between Timaru West and Timaru Main Schools was the main property-related challenge facing Bluestone School when it opened for the first time in February 2005.

1. For more information on school property funding in New Zealand, see PEB Exchange no. 53, October 2004. 
The school is being redeveloped into learning pods of four to six classrooms with a central multipurpose space, a shared teacher office, in-class wardrobes vented to the ceiling to replace cloakrooms, storage rooms and retreat rooms off classes.

"Classrooms are gutted of sinks and fixed furniture to enable greater teaching space and flexibility. New furniture caters for different learning and teaching styles," said Principal lan Poulter.

Other features of the new property modifications include acoustic ceiling panels, sound absorbent wall and wardrobe coverings, and skylights to increase natural light. Storage areas are maximised by mobile shelving.

The property modifications have had a positive impact on teaching and learning. According to Poulter, "Teachers in the two completed pods are thrilled with the teacher offices which encourage collegial support and team-wide planning. Personal teaching resources are easily accessible."

The multipurpose spaces, subconscious learning features and thoughtful landscaping will ensure that learning is not simply confined to the classroom. The principal described the new outdoor areas: "Paths will have a row of bricks across them every five metres allowing students to quickly appreciate varying distances. With an increased enrolment it has been vital to fully utilise outside areas. Chess boards, sails, seats and gardens will provide an attractive environment for the school community. Two new adventure playgrounds will provide challenges for the students."

\section{Bibliography}

ACNielsen (2004), "Best Practice in Classroom Design", survey results, www.minedu.govt.nz/goto/classroomdesignsurvey.

Deaker, Michael (2005), "Property for Improved Learning", examples of school remodels, www.minedu.govt.nz/goto/ schoolremodels.

Feltham, Sarah (2005), "Classrooms - The Insiders' View", Education Gazette, Vol. 84, No. 12, Wellington, 4 July, www. edgazette.govt.nz.

Feltham, Sarah (2005), "Design Examples", Education Gazette, Vol. 84, No. 12, Wellington, 4 July, www.edgazette.govt.nz.

Feltham, Sarah (2005), "Structures for Learning", Education Gazette, Vol. 84, No. 12, Wellington, 4 July, www.edgazette. govt.nz.

"Performing Classrooms", research on school property and factors that influence design and effectiveness, www.minedu. govt.nz/index.cfm?layout=search_results\&criteria=performing $\%$ 20classrooms.

For more information, contact:

Bruce Sheerin, Senior Policy Analyst (Property)

Ministry of Education, Wellington, New Zealand

Fax: 6444638292

E-mail: bruce.sheerin@minedu.govt.nz

\section{THE UNIVERSITY OF SALAMANCA'S NEW CAMPUS}

The University of Salamanca in Spain has planned a new campus rooted in the local culture, geography, architecture and academic tradition. It will be built in the adjacent municipality of Villamayor, along the bank of the river Tormes. The master plan defines the basic features for what is one of the most important university development projects in Europe.

This campus will be an extension of the university's existing buildings which date from 1218 and are located in the city of Salamanca, inscribed on UNESCO's World Heritage List.

"Ours is a very old university, the fifth oldest in Europe. Since its creation in 1218, good architecture, in the widest sense, has been a companion of the University of Salamanca: good times, good architecture; bad times, bad architecture or none at all. You can find fine examples here of the Spanish Renaissance style - the so-called plateresco - and some of the best Baroque buildings and outdoor spaces.

"We seem to be in good shape now, so we are embarking on an ambitious project under the direction of Pablo Campos, the Villamayor campus. Villamayor is a small town near Salamanca whose quarries provided the distinctive sandstone of our historic buildings. With this project we wish to test a new concept in academic architecture."

- Enrique Battaner, Rector of the University of Salamanca

\section{The "educational campus"}

The future university space was conceived as an "educational campus", linking education, architecture and nature. It will encompass open spaces, the landscape and indigenous vegetation as active elements for learning.

The campus layout consists of three academic zones connected by a botanical park that runs along the riverside: the South Area for agricultural and environmental studies; the North Area for communications and the arts, and the East Area which will accommodate a science park. The campus will host 1500 to 2000 students (today the university counts 32000 students).

"The Villamayor campus will embody a new concept of educational campus which recognises students not as products of the learning process but as creators of their own academic activity."

- Santiago López, Vice-Rector of Strategic Planning, University of Salamanca 